\title{
Financial Distress of Pharmaceutical Companies in Indonesia
}

\section{Bintang Mukhammad Burhanudin Akbar, Noer Azam Achsani, Tubagus Nur Ahmmad Maulana}

School of Business, Faculty Management and Business, Bogor Agricultural University, Bogor, Indonesia

\section{Email address:}

bintangmba11@gmail.com (B. M. B. Akbar)

\section{To cite this article:}

Bintang Mukhammad Burhanudin Akbar, Noer Azam Achsani, Tubagus Nur Ahmmad Maulana. Financial Distress of Pharmaceutical Companies in Indonesia. International Journal of Finance and Banking Research. Vol. 5, No. 6, 2019, pp. 174-179. doi: $10.11648 / j . i j f b r .20190506 .16$

Received: September 27, 2018; Accepted: May 10, 2019; Published: December 17, 2019

\begin{abstract}
Many pharmaceutical companies run into financial problems, while the pharmaceutical sub-sector is a vital industry that manufactures and sells pharmaceutical products in Indonesia. Currently the pharmaceutical sub-sector faces government policies related to the application of e-catalogs, BPJS health policies and very high dependence on raw materials in producing drugs. The panel data regression method is used with two models of financial distress companies, altans and DSC in predicting financial problems with a sample of 7 companies that have been listed on the Indonesian stock exchange. In addition, this study was conducted to determine the condition of financial distress on stock returns. The results are known to show that there is a decrease in financial ratios in each company, this has implications for the decline in the financial distress model. At the same time it was known that there was a decline in returns of shares from each pharmaceutical company.
\end{abstract}

Keyword: Financial Distress, Stock Return, Pharmacy

\section{Introduction}

Consumption industry is industries that has increased in value every year, but in 2015 to 2016 the percentage decreased compared to other industries. The high contribution of the consumption sector cannot be separated from the support of its supporting sub-sectors. It is known that the pharmaceutical sub-sector has a large share in business activities in real and financial terms. From 2011 to 2016 all sub-sectors in the consumption industry experienced fluctuations in contributing.

The pharmaceutical sub-sector is one of the sub-sectors that enter the consumption industry. It is known that the pharmaceutical sub-sector has a percentage reduction of one percent annually. Whereas the pharmaceutical sub-sector which is a vital industry that produces and sells medicinal products in Indonesia. It is known that 50-60 percent of the turnover of the pharmaceutical sub-sector is known to be sourced from hospitals which are health service units. Wirdus [1] explains that there are two unique pharmaceutical subsectors, namely basic research and development in the community. In addition, it was explained that the pharmaceutical sub-sector ranks 4th rank (software, oil and food) with a percentage of profit of 13.27 percent where the industry average is 10.19 percent.

Currently the pharmaceutical sector is facing the impact of government policies related to e-catalog, which is a system of purchasing goods and services electronically. This system has been started since April 2013. Basically this policy has a very good impact on the procurement of medicinal products. According to Sutriatmoko [2] in his research, that e-catalog can provide efficiency in procuring drugs. On the other hand this policy can have a negative impact on companies that cannot win drug procurement projects. Where there will be a reduction in sales and products that disrupt the financial condition of the company.

The policy of BPJS Kesehatan which focuses on the pharmaceutical aspect to be able to control the costs and quality, is supported by Article 108 of Law 36/2009 and PP 51 of 2009 . This makes the pharmaceutical industry increasingly squeezed where they are prioritized to produce generic drugs even though they are still allowed to produce 
drugs ethical. This immediately resulted in a decline in average turnover of $20-60$ percent, although the number of drug requests increased from 94 million doses to 240 million doses [3].

The pharmaceutical sub-sector is an industry that relies heavily on raw materials in producing drugs. According to the Ministry of Health in 2016 through the Directorate General of Ministry of Health and Medical Devices said that the Indonesian pharmaceutical industry is still very dependent on raw materials from abroad, especially China and India. It was noted in 2016 that at this time Indonesia was still importing almost 95 percent of the raw material for the medicine. This is realized to be a problem in the future for the country and especially pharmaceutical companies in Indonesia.

Potential and threats from the pharmaceutical industry are considered to affect the stock price of each company. Share prices can be used as a benchmark for the progress of the company. On this basis several formulations of problems were prepared including:

a. What are the company and financial characteristics of each pharmaceutical company?

b. What are the financial distress conditions of each pharmaceutical company, through a corporate financial distress approach and the Altman Z?

c. What is the effect of financial distress on pharmaceutical companies' stock returns?

\section{Methods}

\subsection{Location and Time of Research}

This research with the topic of financial distress will be carried out in the pharmaceutical company sub-sector that has been listed on the Indonesia Stock Exchange since 20132017. Where this research will be conducted from December 2017 - July 2018.

\subsection{Sources and Data Collection Methods}

In this study using secondary data that has quantitative and qualitative properties. Where data and information are obtained from annual reports published by the company, data from the Financial Services Authority, Bank Indonesia, literature and other supporting journals. Known companies are DVLA, INAF, KAEF, KLBF, MERK, TSPC, MERK, SQBI.

\subsection{Analysis Method}

In this study using the panel data regression equation model, which uses 7 companies for 5 years. In addition in this study using two models to get results that are suitable for research purposes.

Altman Z Score

The first model uses the Altman Z Score Manufacturing model which consists of 5 variables, as for the following:

$$
\mathrm{Z}=1,2 \mathrm{~T}_{1}+1,4 \mathrm{~T}_{2}+3,3 \mathrm{~T}_{3}+0,6 \mathrm{~T}_{4}+1 \mathrm{X}_{5}
$$

$\mathrm{T} 1=$ Working Capital / Total Assets

$\mathrm{T} 2$ = Earnings balance $/$ Total Assets

T3 $=$ Earning Before Interest Tax / Total Assets

T4 = Market value of equity / book value to liabilities

$\mathrm{T} 5=$ Sales / total assets

$Z>2.9$ safe company

$1.81<\mathrm{Z}<2.9$ vulnerable company

$\mathrm{Z}<1.81$ Distress Company

Debt Service Coverage

In this model is used as a comparison with other models and calculates the ability of the company to meet its fixed costs by entering the principal payment element or principal installment of the loan. What is meant by a fixed expense in this ratio is the interest on long-term debt along with loan principal installments and rental costs. As follows:

$$
D S C=\frac{(E A T+(\text { Dept }+ \text { Amort })+\text { Interest and or Coupon })-T a x}{\text { Principle }+ \text { Interest and Our Coupun }}
$$

DSC $>1.2=$ Safe Company

DSC $<1.2=$ Distress Company

\section{Result and Discussion}

\subsection{Characteristics of the Pharmaceutical Industry Listed on the Indonesia Stock Exchange}

In Indonesia the pharmaceutical industry can be classified into several types based on their form and capital formation. Can be seen from the characteristics of the pharmaceutical industry listed on the IDX until 2018, including:

Tabel 1. Characteristic Pharmaceutical Industry

\begin{tabular}{lll}
\hline Company & Retail & Manufacture \\
\hline Kimia Farma & $\sqrt{ }$ & $\sqrt{ }$ \\
Indofarma & $\mathrm{x}$ & $\sqrt{ }$ \\
Temposcam & $\mathrm{x}$ & $\sqrt{ }$ \\
Kalbe Farma & $\mathrm{x}$ & $\sqrt{ }$ \\
Daryavaria & $\mathrm{x}$ & $\sqrt{ }$ \\
Taisho & $\mathrm{x}$ & $\sqrt{ }$ \\
Merk & $\mathrm{x}$ & $\sqrt{ }$ \\
\hline
\end{tabular}

Based on the table above it is known that there are three categories of capital investment. Investment of Foreign Capital (IFC) is a form of investment by building, buying in total or acquiring companies that are sourced from all capital originating from abroad. In this type of IFC, it has the advantage of superior research \& development activities and patents that allow companies to sell their products at prices according to their decisions. In Domestic Investment (DI) which capital is obtained from and originating from within the country. It is known that there are two categories including DI owned by private companies and Gouverment Direct Investment. In this type of domestic investment has the characteristic that is using a patent drug that has been used up, for private domestic investment is usually more free in the sale of drug types (OTC and generic). The Gouverment Direct Investment has the characteristics of carrying out the 
government's vision and mission in order to create medicines that are affordable by the community.

\subsection{Financial Characteristics of Pharmaceutical Companies Listed on the Indonesia Stock Exchange}

\section{a Activity Ratio}

In the activity ratio reflected through working capital turn over, fixed asset turn over, total assets turn over and receivable turn over are obtained some important images that can be related to the condition of the financial average of each company in the pharmaceutical sub-sector, According to Otom [4] it is known that the activity ratio can provide information about the initial conditions of the company related to financial problems. as for the following picture:

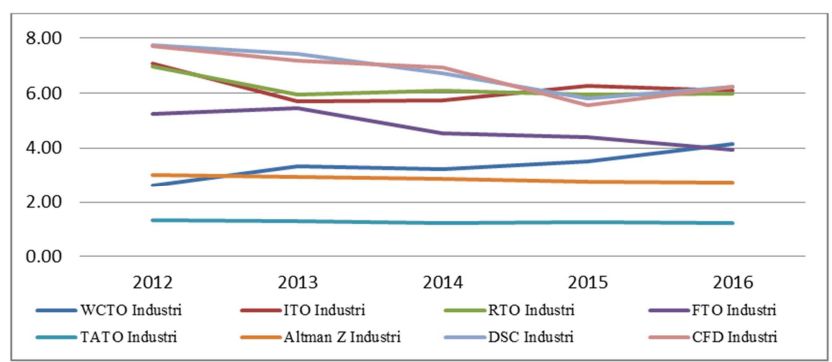

Figure 1. Activity Ratio.

Based on the picture, it is known the relationship of each ratio in the financial condition. Working capital turn over is known to have a positive trend while altman z score and DSC tend to have a negative trend, which means that it represents the opposite so that it can be interpreted that currently even though the financial condition tends to be poor in the pharmaceutical sub-sector, working capital turnover is increasing every year.. The total asset turn over fixed is known to have a value that tends to be stagnant, meaning that the comparison between sales growth with assets owned tends to be balanced in each year, but when compared to the ratio of financial conditions have a different direction. Asset turn over ratios have the same negative trend as altman $\mathrm{z}$ score and DSC financial ratios. So that it can be interpreted in the pharmaceutical sub-sector due to sales growth not higher than the fixed asset growth of each company. In receibable ratio turn over is known to have a pattern of stagnant values in each year so it can be interpreted that this value is different from the ratio of financial conditions that tend to decrease or negative in each year. It is known that the company's sales each year continue to grow but are followed by the same proportion of accounts in each year.

b Profitability Ratio

In profitability ratios which are reflected through net profit margins, return on assets and return on equity obtained several important images that can be related to the condition of the financial average of each company in the pharmaceutical sub-sector. Syaidati [5] states that the profitability of a company affects the company's financial condition. as for the following picture:

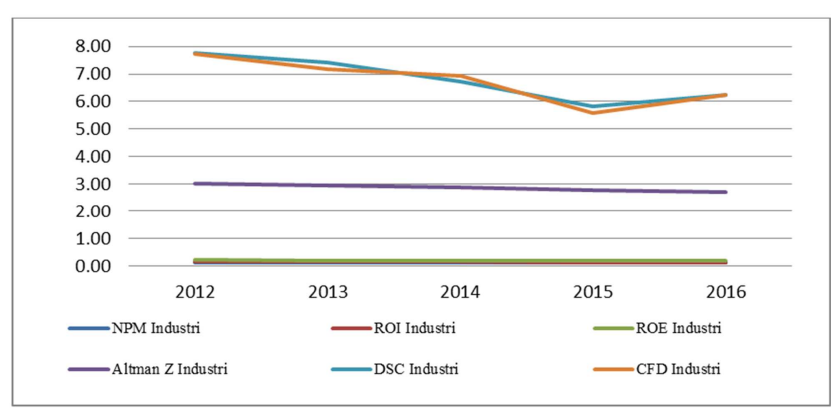

Figure 2. Profitability Ratio.

Based on the picture above it is known that net profit margins, return on assets and return on equity have a downward trend. It is known that the average net profit has increased even though there is an anomaly in the state-owned company, Indofarma, which is recorded as having a negative value. On the other hand it is known that the net profit growth rate in the company is not proportional to the growth of equity and corporate assets that continue to grow, thus it can be said in 2012 to 2016 pharmaceutical sub-sector companies are not effective in managing their business activities.

c Laverage ratio

In the solvency ratio, which is reflected through net profit margins, return on assets and return on equity, there are some important images that can be related to the condition of the financial average of each company in the pharmaceutical sub-sector. Dijelaskan oleh Ong'era et al [6] that when a company is in trouble, it will increase the amount of its debt. as for the following picture:

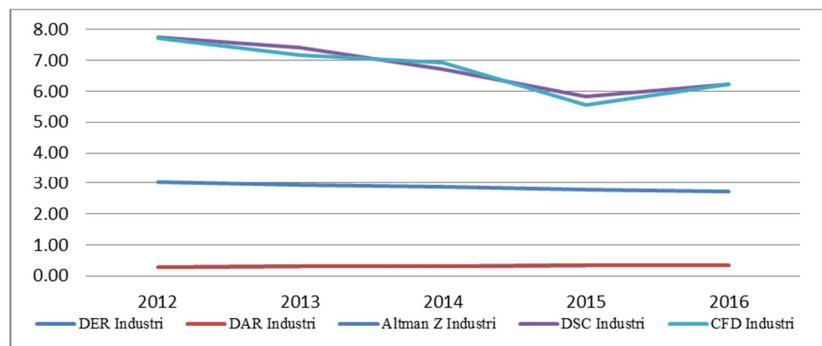

Figure 3. Laverage Ratio.

Based on the picture above, it is known that the current ratio has a value that tends to decline in each year, this indicates that there is an improvement or the company is increasingly paying for its short-term obligations. But on the other hand the three ratios used in determining the financial condition of the company in the pharmaceutical sector provide a declining picture, this is possible for the influence of other variables. The value of a quick ratio that only considers available funds and accounts receivable experiences the same thing as the current ratio, which has a value that tends to decline in each year. So that it can be said that the company is basically able to finance its current liabilities. cash ratio is used to see how far the ratio of other liquidity is. In this case the cash ratio shows the same value as the other liquidity ratios which have a value that tends to 
decline in each year.

d Liquidity Ratio

In the liquidity ratios reflected through current ratios, quick ratios and cash ratios, there are some important figures that can be related to the condition of the financial average of each company in the pharmaceutical sub-sector. Zohra et al [7] companies that have high liquidity will be relatively safe from financial problems. as well as the following:

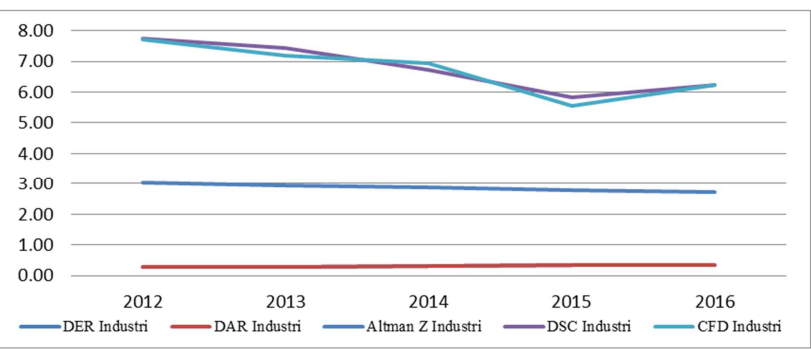

Figure 4. Liquidity Ratio.

Based on the picture above, it is known that the current ratio has a value that tends to decline in each year, this indicates that there is an improvement or the company is increasingly paying for its short-term obligations. But on the other hand the three ratios used in determining the financial condition of the company in the pharmaceutical sector provide a declining picture, this is possible for the influence of other variables. The value of a quick ratio that only considers available funds and accounts receivable experiences the same thing as the current ratio, which has a value that tends to decline in each year. So that it can be said that the company is basically able to finance its current liabilities. cash ratio is used to see how far the ratio of other liquidity is. In this case the cash ratio shows the same value as the other liquidity ratios which have a value that tends to decline in each year.

\subsection{Conditions of the Company's Financial Distress}

The pharmaceutical industry is a growing industry in Inndonesia at the moment, proven from 2012 to 2016 it continues to increase almost 10 percent annually. Besides that, it is known that there is a shift in the composition of drug sales by type, where in 2013 it was found that 8.3 percent of sales were for unbranded generic drugs, 50.7 percent for branded generic drugs and 41 percent for OTC types, while in 2014 there was a change in the composition of OTC which gives high profit share to $39.6 \%$, where branded generic becomes larger to 51.7 percent. Based on the financial statements arranged in the model used to prove the company's financial condition, the results are as follows:

Tabel 2. Result Factpr Financial Distress.

\begin{tabular}{lllll}
\hline Variable & Coefficient & Std. Error & t-Statistic & Prob. \\
\hline C & -8.510819 & 20.74120 & -0.410334 & 0.6862 \\
NPM & 67.74301 & 14.43324 & 4.693543 & 0.0002 \\
CR & 0.189625 & 0.396535 & 0.478206 & 0.6380 \\
HJTDT & 0.083486 & 0.115214 & 0.724614 & 0.4775 \\
ETA & 7.781574 & 2.514188 & 3.095064 & 0.0060 \\
\hline
\end{tabular}

\begin{tabular}{lllll}
\hline Variable & Coefficient & Std. Error & t-Statistic & Prob. \\
\hline RETA & 9.960850 & 3.481456 & 2.861116 & 0.0100 \\
EBITDATA & -30.78476 & 15.33177 & -2.007907 & 0.0591 \\
INF & -0.013133 & 0.038573 & -0.340478 & 0.7372 \\
KURS & -0.363527 & 1.813524 & -0.200453 & 0.8433 \\
GDP & 1.160460 & 1.047721 & 1.107604 & 0.2819 \\
\hline
\end{tabular}

Christananda et al [8] memberikan penjelaskan bahwa NPM memiliki pengaruh signifikan untuk mengetahui kondisi financial distress dari suatu perusahaan. Assaji dan Machmuddah [9] menjelaskan profitabilitas sangat menunjukan peranan penting bagi kesehatan keuangan perusahaan. Murni [10] memiliki pengaruh untuk menjauhkan perusahaan dari permasalahan keuangan, artinya semakin tinggi NPM maka semakin aman perusahaan tersebut. Bakhri et al. [11] menjelaskan bahwa profitabilitas dari suatu perusahaan menjadi informasi dasar bagi investor untuk mengetahui keseahtan perusahaan, bila suatu perusahaan baik maka dapat terlihat dari NPM yang tinggi atau positif. Beaver \& Correia [12] menjelaskan bahwa suatu perusahaan dapat dikatakan mengalami permaslahan keuangan ketika tidak bisa mampu mencetak keuntungan, dari pengeluaran investasi dan operasionalnya.

Islami \& Rio [13] menjelaskan bahwa ekuitas suatu perusahaan menjadi bagian penting yang mampu memberikan gambaran mengenai kekuatan pembiayaan dari dana sendiri dari pada utang. Besaran dari utang suatu perusahaan berperan dalam mengetahui keseahtan keuangan, maka dari itu semakin besar utang suatu perusahaan maka akan memberikan pandangan bahwa perusahaan tersebut tidak aman Campbell et al. [14]. Suntratuk [15] menjelaskan bahwa perusahaan yang dibiayai oleh modal sendiri akan aman dari risiko kegagalan pembayaran utang, namun biasanya memiliki cost of equity yang lebih mahal dari pada dengan berutang. Masdupi et al [16] menjelaskan bahwa kekuatan aset suatu perusahaan dipandang penting dalam menjaga kesehatan keuangan perusahaan, hal ini disebabkan karena perusahaan akan lebih aman namun perlu diketahui kembali mengenai sumber pembiayaan. Sumaryati \& Tristiarini [17] memberikan gambaran bahwa biaya dari modal sendiri (ekuitas) lebih mahal namun jauh dari risiko dari kegagalan

Comparison of altman with DSC S is done to determine the accuracy of the model being tested. There is a summary of the two ratios for each pharmaceutical sub-sector company. As for the following:

Tabel 3. Company Condition Financial Distress.

\begin{tabular}{ll}
\hline Company & Condition \\
\hline Darya Varia & Safe \\
Kimia Farma & Distress DSC \\
Indofarma & Distress DSC \\
Kalbe Farma & Safe \\
Merck & Safe \\
Tempo Scam Pasific & Safe \\
Taisho & Safe \\
\hline
\end{tabular}

Based on the picture above, it is known that the corporate financial distress model developed by Pranowo et al [18] is 
more sensitive in measuring the company's financial condition. This is evidenced by several phenomena where the company is in a safe and distress position.

\section{Discussion}

Based on research conducted related to the financial distress of the pharmaceutical sub-sector, several important things are known:

a. Every company must be able to know their abilities well. It is known that pharmaceutical companies are strong in manufacturing and sales activities, but basically pharmaceutical companies were initially established to produce drugs. So companies need to find the best combination in drug production activities in order to achieve optimal benefits. One of them is by building the construction of a drug raw material factory itself.

b. Companies in the pharmaceutical industry are currently facing changes in government policies. Where this affects the performance of each company. On the other hand the assets of each company are known to continue to grow. This condition can be made an issue in order to assure investors that the company is making a large investment in order to increase capacity in serving the needs of medicine in Indonesia and abroad, the greater the need.

c. The performance of the pharmaceutical sub-sector in 2012 to 2016 is known to have a downward trend (negative), but there are still companies that are still able to share profits with investors. On this basis investors must know a lot of information about the pharmaceutical company that will be chosen as the investment vehicle. One of them is by knowing the products that are traded and the variety of products

\section{Conclusions}

\subsection{Summary}

a. The pharmaceutical sub-sector in Indonesia is known to have several categories of categories based on capital and type of business. It is known that in the capital category there are three groups, namely 1) foreign investment consisting of BRAND and SQBI, which have advantages in research \& development. 2) Private domestic investment consisting of KLBF, TSPC and DVLA which have advantages in selling branded products. 3) SOE domestic investment consisting of KAEF and INAF which have advantages in generic drug products. In addition, in the category of business type only KAEF has a type of retail business in addition to its principal, namely manufacturing.

b. The company's financial condition is illustrated by several ratios used in several ratios used in predicting financial distress. As for some important things in the ratio include: In the activity ratio, it is known that there are no pharmaceutical companies listed on the Indonesia Stock Exchange according to the criteria set. In addition, in the industry picture, the activity ratio tends to decrease every year, indicating that there is a slowdown in the activities of each company. It is known that there are no pharmaceutical companies that have profitability ratios in accordance with the criteria. In addition, in the industry picture, all ratios show a decreasing value every time. At this ratio, it is known that all pharmaceutical companies listed on the Indonesia Stock Exchange have loans below the criteria set or can be interpreted to still be able to increase loans in financing their activities and investments. It is known that all pharmaceutical companies are included in the current ratio criteria. While in the cash ratio and quick ratio, there are two companies, KAEF and INAF, which are included in state-owned enterprises which have incompatible criteria in 2015 and 2016.

c. Pharmaceutical companies that fall into the category of distress. Where the pharmaceutical company is included in the group of BUMN companies, while in the group of private domestic and foreign companies are not included in the category of distress. In the three ratio equations (altman and DSC) that are used to predict the stock returns of each whole pharmaceutical company have a significant negative effect on stock returns. This indicates that all indicated pharmaceutical companies have decreased performance. In the altman and DSC equations, it is known that only the variable gross domestic product is considered to have a strong influence on the stock returns of pharmaceutical companies.

\subsection{Recommendations}

The recomendation that can be submitted to investors and several interested parties include:

a. Basically, the Indonesian pharmaceutical industry is currently developing with an increase in sales, but since 2014 or after government policy through the BPJS, the impact of a decline in profits in the pharmaceutical industry as a whole. On the other hand pharmaceutical companies need to start thinking about corporate actions in order to overcome these policies so that companies can get out of trouble. In addition, the pharmaceutical industry in Indonesia is still heavily bound by raw materials originating from abroad, this can have an impact on financial problems when economic conditions are not good or not in favor of Indonesia.

b. Investors need to identify more in order to determine which industries and companies are feasible and appropriate to be chosen as investments. Investors can use a corporate financial distress model in order to know the financial condition and stock returns that can be obtained from the decision.

c. This research still has many weaknesses, so the researchers suggest to conduct a study related to the right time to invest in the pharmaceutical industry. 


\section{References}

[1] Wirdus, Setiawan. 2001. Cara Sehat Investasi di Pasar Modal. Jakarta (ID): Media Komputindo.

[2] Sutriatmoko. 2015. Analisis Penerapan e-procurement obat dengan prosedur e-purchasing berdasarkan e-catalogue di dinas kesehatan kabupaten/kota di jawa tengah [tesis]. Yogyakarta (ID): Universitas Gadjah Mada.

[3] Direktorat Jendral Kefarmasian dan Alat Kesehatan. Laporan Kinerja 2016. Jakarta (ID): Kementrian Kesehatan.

[4] Otom, Robert Odero. 2014. Predicting Financial Distress Using Financial Ratios In Companies Listed In Nairobi Stock Exchange (2003-2011).

[5] Syadiati, Winwin. 2017. The Influence Of Profitability On Financial Distress: A Research On Agricultural Companies Listed In Indonesia Stock Exchange. International Journal Of Scientific \& Technology Research. 6 (11).

[6] Ong'era, Joshua B. Muturi, Willy. Oluoch, Oluoch. Karanja, John Ngugi. 2017. Leverage as Financial Antecedent to Financial Distress among Listed Companies at Nairobi Securities Exchange. Research Journal of Finance and Accounting. 8 (6).

[7] Zohra, Kerroucha Fatima. Mohamed, Bensaid. Elhamoud, Turki. Garaibeh, Mohamed. Ilhem, Attaoui. Naimi, Halim. 2015. Using Fiancial Ratios to Predict Financial Distress of Jordanian Industrial Firms Empirical Study Using Logistic Regression. 4 (2).

[8] Christananda c, Khairunnisa, Nurbaiti a. 2017. Analysis of current ratio and net profit margin for predicting financial distress condition of the company (study of textile and garment company listed in indonesia stock exchange period 2010-2015). E-proceeding of management. 4 (1).

[9] Assaji JP, Machmuddah Z. 2017. Rasio keuangan dan prediksi financial distress. Jurnal Penelitian Ekonomi dan Bisnis, 2 (2).

[10] Murni M. 2017. Analisis faktor-faktor yang mempengaruhi tingkat financial distress pada perusahaan manufaktur yang terdaftar di bei tahun 2010-2014 Jurnal Akuntansi dan Bisnis. $4(1)$.

[11] Bakhri S, Lisyaningsih E, Nurbaiti. 2018. Pengaruh Likuiditas Dan Profitabilitas Terhadap Financial Distress Pada Perusahaan Transportasi Yang Terdaftar Di Bursa Efek Indonesia Periode 2014-2016. Jurnal Riset Akuntansi dan Manjemen, 7 (1).

[12] Beaver WH, Correia M. 2011. Financial Statement Analysis and the Prediction of Financial Distress Foundation and Trends R in Accounting, 5 (2).

[13] Islami IN, Rio W. 2018. Financial Ratio Analysis to Predict Financial Distress on Property and Real Estate Company listed in Indonesia Stock Exchange. (Journal of Applied Accounting and Finance. 2(2).

[14] Campbell JY., Jens DH, Jan S. 2011. Predicting financial distress and the performance of distressed stocks. Journal of Investment Management 9 (2): 14-34.

[15] Suntratuk P. 2017. Predicting Financial Distress: Evidence from Thailand [Thesis] Martin De Tours School of Management of Assumption University.

[16] Masdupi E, Tasman A, Davista A. 2018. The Influence of Liquidity, Leverage and Profitability on Financial Distress of Listed Manufacturing Companies in Indonesia. Advances in Economics, Business and Management Research, volume 57 (1).

[17] Sumaryati A, Tristiarini. 2017. The Influence of Cost of Equity on Financial Distress and Firm Value. Advances in Economics, Business and Management Research. 46 (1) .

[18] Pranowo, Koes. Achsani, Noer Azam, Manurung, Adler H. Nuryantono, Nunung. Determinant of Corporate Financial Distress in an Emerging Market Economy: Empirical Evidence from the Indonesian Stock Exchange 2004-2008. International Research Journal of Finance and Economics. 52 (1). 